\title{
Even an editor needs an editor: reflections after five years at CMAJ
}

$\mathrm{E}$ veryone needs an editor. This is an old saying that has taken me five years to appreciate fully. When I assumed the editorship of CMAJ in January 2007, I was given an amazing opportunity - the chance to learn about the inner workings of a scientific publication. As a clinician researcher, I had extensive experience with peer review, but I lacked formal editorial training and had a limited view of the editor's role. That quickly changed as I discovered that editors do much more than help fashion the content of articles.

I was also astounded at the extent to which medical journals and their editorial teams influence public discourse. I believe it is because they are a safe space to debate ideas. To be effective in doing so, reputation and credibility are essential. As a collective, editors of major medical journals set high standards. ${ }^{1}$

Over the past years, I've learned a few things about the essential role medical editors play in disseminating "medical knowledge that matters" in this safe space.

Lesson 1: Researchers excel at being creative and scientifically credible, but they aren't necessarily good communicators and writers. This is where editors come in. I have learned that editors substantially shape manuscripts. Only a small part of the job involves correcting grammar and syntax. We spend most of our time overseeing and conducting peer review that guides detailed revisions on substantive parts of the scientific conduct, analysis and reporting of studies. We, as editors, set the bar high. And authors rise to the challenge, often meeting or exceeding expectations. Prompting this performance is a real skill, an art that depends on aptitude and years of training.

Lesson 2: Medical journals are no longer aimed solely at physicians and scientists. The audience is much broader, and the role of the journal has likewise expanded. Our credibility and evidence-based, thoughtful perspectives provide us a platform as we increasingly delve into the public arena shaping scientific thought and stimulating public discourse. In editorials, we set the agenda by tackling complex social, public health or ethical concerns. For instance, $C M A J$ has taken on issues related to public health such as SARS and H1N1, food and drug safety, tobacco labelling and major issues affecting the way governments influence our health and the delivery of health services.

Lesson 3: To fulfil these essential roles in Canada and elsewhere, we need to train the editors of tomorrow. In Canada, we have a very small scholarly publishing industry. As a consequence, there are few medical editing positions, no obvious career paths and even fewer training opportunities. In contrast, the United Kingdom has well-established medical editing career paths and training programs.

Given the seminal role played by editors, we need to rectify this. Editors not only can take on leading roles at journals but also can learn essential skills for disseminating one's own work or that of others. I believe that electives for medical students and resi- dents and editorial fellowships will help define a variety of career paths that will ultimately improve the ability of Canadian scientists to communicate their findings. Faculties of medicine must help develop programs to improve written communication and advocacy. Ideally, they should develop strategies to support career paths in medical editing in collaboration with major journals.

Given that major medical journals and the teams that give them life are a public good, ${ }^{2}$ they need much greater support and recognition by our community, journal owners and research funding agencies.

After five years, I have learned another truth — publishing a major journal every week is a team effort by people who are passionate about what they do. If $C M A J$ is in a better place than it was five years ago - and I believe it is - it is because of the high-calibre team of professionals I worked with every day.

I have learned that one always stands on the shoulders of those who came before you. I am keenly aware that I have stood on the shoulders of many great editors, from the journal's first editor Sir Andrew Macphail to my recent predecessors Dr. Noni E. MacDonald, Dr. John Hoey and, the late and much missed, Dr. Bruce Squires. Noni helped during a difficult transition. John gave CMAJ a strong and unique voice in the world. Bruce helped put Canada on the international stage by founding World Association of Medical Editors, giving it a voice that could be heard beyond our borders.

Thank you for the privilege and honour of serving as CMAJ's editor. But more important, thanks to you, our readers, for giving us your most precious asset — your time — as you have perused our pages.

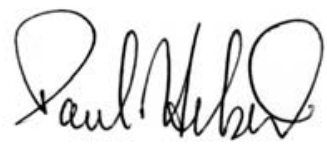

Paul C. Hébert MD MHSc

\section{References}

1. Uniform requirements for manuscripts submitted to biomedical journals: writing and editing for biomedical publications. International Committee of Medical Journal Editors; 2009. Available: www.icmje.org/ (accessed 2011 Oct. 1)

2. Sox HC. Medical journal editing: Who shall pay? Ann Intern Med 2009;151:68-9.

Competing interests: See www.cmaj.ca/site/misc/cmaj_staff.xhtml

Affiliations: See www.cmaj.ca/site/misc/cmaj_staff.xhtml

Correspondence to: $C M A J$ editor,pubs@cmaj.ca

Acknowledgements: Many thanks to editorial advisory team members Matthew B. Stanbrook MD PhD, Noni E. MacDonald MD MSc, Ken Flegel MDCM MSc and Daniel Rosenfield MD. Thanks also to Barbara Sibbald BJ and Kim Barnhardt who contributed to various drafts of this editorial.

CMAJ 2011. DOI:10.1503/cmaj.111641 